\title{
Public infrastructure for food and nutrition security in brazil: fufilling the constitutional commitment to the human right to adequate food
}

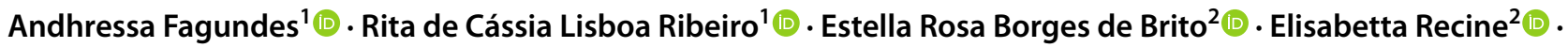 \\ Cecilia Rocha ${ }^{3}$ (]
}

Received: 18 June 2021 / Accepted: 13 February 2022 / Published online: 3 March 2022

(c) International Society for Plant Pathology and Springer Nature B.V. 2022

\begin{abstract}
Food insecurity is a critical global problem with social and public health consequences. In Brazil, access to adequate food is a fundamental human right guaranteed under the country's Constitution since 2010. As such, the State assumes the distinct and complementary obligations to respect, protect, promote and provide the Right to Adequate Food. The aim of this study is to present actions related to the "provision" dimension that have been developed as part of a network of public infrastructure strategies for food and nutrition security in Brazil. Through an exploratory, analytical literature review, the paper focuses on the operational designs and logistics of three main strategies: Food Banks, Community Kitchens, and Popular Restaurants. The Brazilian experience indicates that public actions are necessary, especially considering the urgency for those groups living with hunger and poverty. While similar programs can be found in other countries in South and North America, they are mostly offered by civil society organizations, and have not advanced toward public institutionalization. In fact, private programs are criticized for negating governments' obligation and responsibility in this area. Brazil's experience sheds light on public initiatives in meeting the State's obligations towards the Right to Adequate Food.
\end{abstract}

Keywords Human rights · Food and nutrition security · Public policy $\cdot$ Nutrition and food programs and policies $\cdot$ Food assistance $\cdot$ Food banks $\cdot$ Community kitchens $\cdot$ Popular restaurant

\section{Introduction}

Food and nutrition insecurity (FNI), understood as an inadequate quantitative and/or qualitative access to food (Brasil, 2014), is a critical global problem with both social and public

Andhressa Fagundes

afagundes16@gmail.com

Rita de Cássia Lisboa Ribeiro

cassialisboar@gmail.com

Estella Rosa Borges de Brito

estellarbbrito@gmail.com

Elisabetta Recine

erecine@gmail.com

Cecilia Rocha

crocha@ryerson.ca

1 Graduate Program in Nutrition Sciences, Federal University of Sergipe, São Cristóvão (Sergipe), Brazil

2 University of Brasilia, Graduate Program in Human Nutrition, Brasilia (District Federal), Brazil

3 School of Nutrition and Centre for Studies in Food Security, Ryerson University, Toronto (On), Canada health implications. Given the multiple determinants of this problem, FNI is one of the major challenges that governments must address (Haug, 2018; IFPRI, 2018). A report by the Food and Agriculture Organization (FAO) of the United Nations (FAO, 2021) points out that, worldwide, 2.3 billion people did not have sufficient access to food in 2020. In Brazil, the household budget survey of 2017-2018 showed that $36.7 \%$ of households in the country presented some level of food insecurity (Instituto Brasileiro de Geografia e Estatistica, 2019). The most recent data indicate that the situation is even worse, with more than half of the Brazilian population $(55.2 \%)$ presenting some level of food insecurity, and approximately 19 million people (9\%) suffering severe food insecurity (hunger) (Rede, 2021).

The Universal Declaration of Human Rights, proclaimed in 1948, includes food as a fundamental social right. It also declares that access to food in quantity, quality and regularity must be a constitutional human right (ONU, 1948). In this conception, the State has the obligation to respect, protect, promote and fulfill this and other human rights (Abrandh, 2013; Brasil, 2006; ONU, 1999). The fulfillment of these maxims is secured via public policies, programs and 
projects designed for their progressive realization (Conti, 2009).

"Every man, woman and child have the inalienable right to be free from hunger and malnutrition in order to develop fully and maintain their physical and mental faculties. Society today already possesses sufficient resources, organizational ability and technology and hence the competence to achieve this objective. Accordingly, the eradication of hunger is a common objective of all the countries of the international community, especially of the developed countries and others in a position to help." (ONU, 1975)

Brazil is not only a State Party of this Declaration by signing the International Covenant on Economic, Social and Cultural Rights, but the country also included the Right to Adequate Food in its Constitution in 2010 (Brasil, 2010). Even earlier, in 2006, with the enactment of the Food and Nutrition Security Law, a National System for Food and Nutrition Security (Sistema Nacional de Segurança Alimentar e Nutricional-SISAN) was created to ensure the Human Right to Adequate Food (HRAF) (Brasil, 2006). SISAN encompasses all policies related to the production, supply, distribution, and marketing of food, as well as the promotion of programs and actions to facilitate regular and permanent access to quality food and healthy and environmentally sustainable eating practices (Brasil, 2006, 2010).

According to General Comment 12 of the UN Committee on Economic, Social and Cultural Rights (ICESCR), the HRAF takes place when every human being, woman and child, alone or with others, has uninterrupted physical and economic access to food or available means of obtaining it (UN Committee on Economic S and CR (CESCR), 1999). International Human Rights treaties define that there are two indivisible dimensions of the HRAF: the right to be free from hunger and malnutrition and the right to adequate food (Abrandh, 2013). The HRAF should not be interpreted in a restrictive sense, which regards it as assigning minimum recommendations for energy or nutrients. It must be understood as a process of transformation of people, considering health and citizenship (CONSEA, 2010), intrinsically linked to the dignity of the human person, in addition to being fundamental for the fulfillment of other human rights.

The ICESCR's General Comment 12 defines the obligations of the State and responsibility of the society to respect, protect, promote and provide: physical and economic access to healthy and sustainable food; as well as conditions that provide adequate care in the choice, preparation and administration of food (hygiene, food preparation, day care, etc.), living conditions that promote health; and comprehensive health care.

The causes of the violation of the HRAF are not solely concentrated in the lack of food, but in large part, in the difficulty of access to available food due to the poverty of segments of the world population (Soares, 2018). The General Comment 12 admits that the main obligation of the State is to adopt measures to achieve, in a progressive way, the full realization of the right to adequate food. This imposes the obligation that this be done as quickly as possible. Given that the HRAF comprises two inseparable dimensions - freedom from hunger and accessibility to adequate food - one of its essential principles is equity in the promotion of actions. Thus, while Food and Nutrition Security (FNS) policies and programs contemplate the population as a whole, priority must be given to the most vulnerable groups and individuals in society.

In the scope of actions that have contributed to the promotion of HRAF in the Brazilian experience over the years, Public Infrastructure for Food and Nutrition Security (Equipamentos Públicos para Segurança Alimentar e Nutricional-EPSAN) gained prominence since 2003 under the Zero Hunger strategy announced by the federal government. This infrastructure consists of public spaces designed to promote integrated services for food and nutrition security through a strategy of strengthening local circuits of food production, supply and distribution (Brasil, 2019).

This paper aims to present key actions related to the dimension of provision of food developed through a network of facilities under the EPSAN program, addressing their respective designs, arrangements and operational logistics. In our analysis we look in particular at how this network was proposed as supporting the Human Right to Adequate Food and to what extent it has succeeded in this goal, given the premise that adequate food goes beyond the strict or restrictive sense of food representing simply a minimum package of calories, proteins, and other specific nutrients that meet people's dietary needs. The concept of adequacy emphasizes a series of factors that must be taken into account, such as social, economic, cultural, climatic, and ecological conditions related to the production and consumption of food. Adequacy is also linked to the idea of long-term accessibility and availability of food (Paiva et al., 2019; United Nations, 2010).

\section{Methodology}

We used an exploratory and analytical literature review of the Public Infrastructure for Food and Nutrition Security. The cut-off points of the research were defined as the three more widespread initiatives in Brazil in the past few years (Brasil, 2010): Food Banks, Community Kitchens, and Popular Restaurants.

The literature review (covering publications from 2009 to 2021) was carried out from October 20, 2018 to October 30, 2021, through searches on the databases of Latin American and Caribbean Health Sciences Literature (LILACS), Scientific Electronic Library Online (SciELO) 
and National Library of Medicine (PubMed), with preference for scientific articles published in the last five years, in addition to searches in official databases published by the government of Brazil. The descriptors used were: Equipamentos Públicos; Equipamentos Sociais; Segurança Alimentar e Nutricional; Banco de Alimentos; Cozinha Comunitária; Restaurante Popular; Assistência Alimentar, in addition to their combinations and translations into English and Spanish (in English: Public Infrastructure/Equipment; Social Infrastructure/ Equipment; Food and Nutrition Security; Food Bank; Community Kitchen, Popular Restaurant; Food Assistance).

All articles that addressed Public Infrastructure as a social policy were considered eligible. The publication period was comprised between 2009 and 2021, including official publications and studies, with the highest volume of publications concentrated between 2014 and 2019. The studies that used those structures as a locus, and not as a topic of research were excluded. Considering that the present study aims to analyze public programs, the kind of research was not a criterion of eligibility.

The titles and abstracts of all articles were read and those that met the eligibility criteria were selected to be read in full. The articles that did not correspond to the primary objective of the research were excluded. The references cited in the eligible articles were also examined in order to assess inclusion of other publications, and complementary searches were performed on official webpages of the institutions connected with the topic, particularly the homepage of the former Ministry of Social Development and Fight Against Hunger (MDS) (RedeSAN, FAURGS, UFRGS \& MDS, 2011), today Ministry of Citizenship, and similar institutions in Brazilian states and cities.

The following steps were then followed: exploratory and selective reading (selection of material); analytical and interpretative reading and writing, according to the infrastructure previously defined (Food Bank; Community Kitchen; Popular Restaurant) seeking information on current scenario and challenges, definition, operation and logistics, in addition to a brief history and evaluation studies on the respective infrastructure.

More current articles were the primary aim; however, the period of the references used was extended, considering that they referred to public programs, institutionalized at different moments.

\section{Public infrastructure for food and nutrition security in Brazil}

The Brazilian experience in the field of social public policies gained momentum with the proclamation of a new Federal Constitution in 1988 and advanced more significantly, in extension and scope, in the 2003-2014 period (Machado et al., 2018; Vasconcelos et al., 2019), especially with the implementation of the Zero Hunger Strategy, conducted by the Federal Government. Many programs and actions to reduce inequalities were developed with broad civil society participation and government commitment. In this period, the Conselho Nacional de Segurança Alimentar e Nutricional (CONSEA, National Council of Food and Nutrition Security) was reconstituted as an advisory agency to the Presidency of the Republic. The Lei Orgânica de Segurança Alimentar e Nutricional (LOSAN, Organic Law of Food and Nutrition Security) was sanctioned, bringing together all levels of government, civil society organizations, entities and private sector to the debate of food and nutrition security policies. Actions on Food and Nutrition Security (FNS) originated in the health and social assistance areas but have evolved into more complex programs with intersectoral coordination and objectives of promoting a sense of citizenship (Silva et al., 2018).

Social Public Infrastructure in Brazil is defined as the facilities and urban infrastructure spaces designed to provide public services such as in education, health, culture, and social assistance (Brasil, 2010). The Public Infrastructure for Food and Nutrition Security (Equipamentos Públicos para Segurança Alimentar e Nutricional-EPSAN) was created with the objective of providing services to support the Human Right to Adequate Food (HRAF).

Comprising physical structures and spaces designed for the distribution of food and meals free of charge or at affordable prices (RedeSAN, FAURGS, UFRGS \& MDS, 2011; Brasil, 2005), the EPSAN program aims to contribute to the reduction of food and nutrition insecurity. To achieve this goal, EPSAN facilities are classified into two main types (Table 1): (1) consumption support, through the provision of affordable food, and (2) supporting food supply and reducing food waste by building local food donation networks for social care institutions and vulnerable populations.

In addition, these public physical spaces often also house programs in nutrition and health education, professionalizing courses and workshops, cultural events, and other social services (Carrijo et al., 2018). The use of these facilities is thus a promising arrangement to enhancing communication/joint efforts of the Food and Nutrition Security System (SISAN), the Social Assistance Unified System (SUAS), and the Unified Healthcare System (SUS).

Since 2003 and the launching of the national Zero Hunger strategy, there has been an expansion of EPSAN facilities, prompted by an annual bidding process promoted by the Federal Government (RedeSAN, FAURGS, UFRGS \& MDS, 2011). Community Kitchens (CK), Popular Restaurants (PR), and Food Banks (FB) are the most prominent components of this public network. According to the Ministry of Citizenship, there were 87 public Food Banks, 104 
Table 1 Classification of Public Infrastructure for Food and Nutrition Security

Public Infrastructure for Food and Nutrition Security

\begin{tabular}{|c|c|c|}
\hline Type: & (1)Support to consumption & (2)Supply of food and fight against food waste \\
\hline $\begin{array}{l}\text { Concept/ } \\
\text { Definition }\end{array}$ & $\begin{array}{l}\text { Adequate facilities for the on-site preparation and consumption } \\
\text { of meals, having as guiding principle the promotion of the } \\
\text { Human Right to Adequate Food }\end{array}$ & $\begin{array}{l}\text { Physical and/or logistic structures that obtain and/or receive } \\
\text { foodstuffs from donations; distribution directed to public or } \\
\text { private institutions that provide social assistance, protection } \\
\text { and civil defense services, schools, legal and healthcare } \\
\text { facilities, and other food and nutrition units }\end{array}$ \\
\hline Objectives & $\begin{array}{l}\text { Ensure access to adequate and healthy food; } \\
\text { Value the use of regional foods; } \\
\text { Develop social inclusion activities; } \\
\text { Train workers for the food sector }\end{array}$ & $\begin{array}{l}\text { Provide availability of adequate and healthy foods; } \\
\text { Support public procurement for foods; } \\
\text { Promote educational activities on nutrition; } \\
\text { Reduce food losses and waste; } \\
\text { Contribute to the HRAF }\end{array}$ \\
\hline $\begin{array}{l}\text { Example of } \\
\text { infrastructure }\end{array}$ & $\begin{array}{l}\text { Community kitchen; } \\
\text { Popular restaurant }\end{array}$ & Food Bank \\
\hline
\end{tabular}

Brazil (2016)

Popular Restaurants, and 189 Community Kitchens in operation in Brazil in 2020.

Data from a 2015 national survey (MapaSAN) conducted within the scope of the National System for Food and Nutrition Security (SISAN) indicated that in the 1,652 Brazilian municipalities which participated in the survey, EPSAN facilities served more than 230,000 individuals directly and more than 16,000 social assistance institutions (Brasil, 2014). Unfortunately, the same survey reported that more than $23.5 \%$ of the infrastructure had discontinued operations.

\subsection{Popular restaurants and community kitchens}

Popular Restaurants (PR) and Community Kitchens (CK) have a long history as public policies in Brazil, first appearing in the 1950's One of their main objectives was to reduce worker absenteeism in the growing industrialized and urbanized economy of the country. At the time, it was assumed that the provision of affordable meals to workers and their families could also be used as an educational strategy, through activities in these spaces, such as nutrition education lectures during meal times, health campaigns, as well as the distribution of booklets and leaflets (Conti, 2009; Oliveira, 2018). Public cafeterias were later closed during the period of military dictatorship (1964-1985), reemerging only after the Popular Restaurant was re-opened in the city of Belo Horizonte in 1994. Later, in 2003, the Brazilian government included PR and CK as programs integrated to the actions of the Zero Hunger strategy (Sobrinho et al., 2014).

Popular Restaurants and Community Kitchens are cafeteria-style spaces offering prepared meals - lunch, and sometimes breakfast and/or dinner - for free or, more often, at subsidized low prices. Their clientele is mostly people living in poverty; but given their universal access, PR and CK also attract low-income students, retired seniors, people who live alone, low-wage workers, and a significant contingent of homeless individuals. They are located in areas where there are large concentrations of people in social vulnerability, facilitating thus their access to an affordable meal (Garajau \& Afonso, 2016). Besides offering healthy meals, PR and CK often serve as spaces for other activities such as training and professional qualification of low-income individuals, aiming at social inclusion (RedeSAN, FAURGS, UFRGS \& MDS, 2011; Brasil, 2005). They are usually open to the public six days a week.

PR and CK differ primarily in their size, infrastructure, and capacity. PRs are larger facilities, found in cities with more than 100 thousand inhabitants, having a capacity to serve up to 400 to 1000 meals per day (Conti, 2009; RedeSAN, FAURGS, UFRGS \& MDS, 2011). In comparison, CK can produce up to 100 meals per day, and are located in municipalities with more than 50,000 people.

In Brazil, the administration of the PR and CK units is the responsibility of local municipal governments, which often contract private companies to manage and staff the facilities. The Federal Government supports the construction and/or renovation of the premises, and the purchasing of equipment. It also provides technical support and inspects the implementation of the programs (Oliveira, 2018; Brasil, 2004).

According to the Manual of the Popular Restaurant Program by the former Ministry of Social Development (MDS) in Brazil, this Public Infrastructure is defined as:

“(...) establishments managed by the government, which are characterized by the sale of ready, nutritionallybalanced meals, originating from safe processes, predominantly made with local foods, served in appropriate and comfortable places so as to ensure the right to feed oneself with dignity. They are intended to provide varied, affordable meals to people who eat outside the 
home, with priority to the most vulnerable populations

(...)" (Brasil, 2004)

(Author's translation)

Research studies have shown positive outcomes with the implementation of PRs and achievement of their goals (Gobato et al., 2010; Godoy et al., 2014; Gonçalves et al., 2011; Leal, 2015; Oliveira, 2018; Padrão \& Aguiar, 2018; Silva, 2012; Sobrinho et al., 2014). PRs provide a continuous service, from Monday to Friday, delivering balanced, good quality and affordable meals, in addition to access to traditional Brazilian foods (Carrijo, 2018). They also contribute to the promotion of healthy eating habits among the population, valuing local cultural habits (Carrijo, 2018; Brasil, 2004).

\subsection{Food banks}

Food Banks aim to distribute food to those most in need, thus reducing food and nutrition insecurity. An additional expressed goal of FB is the reduction of food waste (Brasil, 2015; Garcia, 2013). From a global perspective, the Food Banks (FB) movement grew from the early 1980s to the 1990s as a philanthropic response to the increased FNI situation, especially in Australia, Canada, New Zealand, the UK and the USA. Food Banks are thus mainly private spaces intended to collect donations and redistribute foods to vulnerable people or families (Riches, 2002; Riches \& Silvasti, 2014). The first FB in the world date back to 1967, in the USA.

In Brazil, private food banks were already in existence when public food banks emerged in 2000 as initiatives of some local municipal governments. Federal participation in food banking started only with the Zero Hunger strategy in 2003 (Belik et al., 2012; Brasil, 2015), with the government granting funds for the installation, modernization or expansion of food banks by municipal governments. By 2012 there were 67 food bank units supported by the Ministry of Social Development (MDS), distributing close to 39 thousand tons of food around the country. In 2016, MDS structured the Brazilian Food Banks Network. The idea was to join local experiences, private initiatives and activities of the organized civil society, as a concerted effort to strengthen public policy (Brasil, 2016, 2017).

Food Banks in Brazil consist of physical spaces that receive food donated by supermarkets, restaurants, the food industry, small farmers, and farmers' markets. When delivered to FB, the food is examined, classified and stored for distribution. In some larger FB, food can undergo some minor processing (freeze-dried or canned), and packaged before being distributed. The food is distributed to private (non-governmental and charitable) social assistance entities that attend people in situation of social vulnerability and
FNI (Conti, 2009), (RedeSAN, FAURGS, UFRGS \& MDS, 2011). Public FB do not distribute food directly to individuals or families.

Today, most Brazilian FB are public institutions, receiving funding from the federal government, and managed by municipal administrations. Thus, this FNS public infrastructure depends on public funds to contract professionals to work in the areas of management, sanitary control, and social assistance, as well as the hiring of other workers responsible for receiving, sorting, and preparing food for distribution. Public funding supports the entire physical structure, with a storage area with conditions to stock perishable and non-perishable foods (RedeSAN, FAURGS UFRGS \& MDS, 2011; Rangel, 2016; Tenuta et al., 2017; Paula et al., 2017). The former Ministry of Social Development created guidelines and manuals to govern the installation and operations of public food banks.

\subsection{Rural-urban connections}

Food Banks, Popular Restaurants and Community Kitchens also receive fresh fruits and vegetables directly from smallholder family farmers included in the Food Acquisition Program (Programa de Aquisição de Alimentos - PAA). Developed as part of the Zero Hunger strategy, PAA is a public food procurement program, which purchases food directly from local smallholder producers. It aims to strengthen FNS policies and contribute to the income of small producers (Vasconcelos et al., 2019). In addition to the benefits to local family farmers, the supplied produce is of good quality and with a short circuit (Burlandy, 2009; Rocha, 2014; Silva, 2012). PAA fosters local agriculture and provides high quality, low-cost meals, respecting the cultural aspects of regional dietary practices (Zanini \& Schneider, 2015), in accordance with the objectives of the Food and Nutrition Security Organic Law (Brasil, 2006).

The federal government has also created the Distribution Centers for Family Farming Products (DCFPs) to work as a point of delivery and distribution of food. These are operational units within municipalities, which regularly operate the PAA or the National School Feeding Program (PNAE) with purchases from family agriculture. DCFPs support the receiving and/or distribution of family farming products linked to governmental commercialization programs (Brasil, 2013). There are currently (in 2021) 1,519 DCFP units in operation throughout the country (Brasil, 2013, 2019).

As part of an integrated set of programs for FNS, EPSAN have contributed to decreasing hunger and food insecurity in Brazil. The positive outcomes result from a set of interrelated policies and actions, and not just from one or another isolated program. In this context, the development of a supporting public infrastructure has been crucial. 


\subsection{Challenges}

Vasconcelos et al.'s analysis of the recent history of food and nutrition policies in Brazil proposes three phases with distinct discourses, values, priorities and interests associated with three different governments (Vasconcelos et al., 2019). The period from 2003 to 2010 was very prosperous in the creation of FNS laws and programs, and in prioritizing hunger reduction and the promotion of healthy diets. From 2011 to 2016 , actions for the promotion of healthy eating were strengthened, but at the same time one notes the beginning of a slowdown in FNS programming. In the period since 2016 there have been massive and continuous budget cuts, which weakened policies for hunger and poverty reduction, and for the promotion of FNS.

The challenges in the implementation of EPSAN programs are many. Studies have pointed out differences in regional coverage, underuse of regional foods (Martinelli et al., 2018), and overuse of ultra-processed foods (Calazans et al., 2018), undermining these programs' objectives under SISAN and the HRAF.

Much of the concern about EPSAN units falling short on following the HRAF perspective comes from a polarizing debate on the nature of programs aimed at fighting hunger, whether through income transfer or food distribution. On the one side are those who see these programs as legitimate tools through which the State must secure the rights of individuals through "provision". On the other side of this debate, are those who claim that such programs do not act on the causes of hunger and, therefore, are not effective solutions. This side considers these programs merely "assistentialist" (Araújo et al., 2016; Fonseca et al., 2018), generating dependence on the part of those who access them.

The controversy surrounding Food Banks is probably the best example of this debate. If well structured, FB can be an agile, effective response to FNI situations. Nevertheless, the HRAF perspective raises a reflection on the ethical legitimacy of food donations, supported by transnational and large food industries, questioning who really benefits from them (Riches \& Silvasti, 2014). This concern has been particularly shaped by food banking practices in other countries, such as the USA and Canada, where governments seem to abdicate of their responsibilities and encourage nongovernmental organizations to respond to the serious and increasing FNI problem (Philip et al., 2017). FB in those countries are private, philanthropic institutions, and not part of public services.

In Brazil, there are efforts to make FB gain legitimacy as a public policy for accomplishment of the HRAF (Brasil, 2010; Riches \& Silvasti, 2014; Rocha, 2014). Food Banks consist of structures created within the concept of the Food and Nutrition Security and, therefore, intended to promote adequate and healthy eating. Most units have adequate spaces for handling fruits and vegetables (Burlandy, 2009), which is vitally important to avoid the situation of FB becoming outlets for unhealthy products, aggravating health problems such as obesity, diabetes and high blood pressure (Pipkin, 2016; Seligman et al., 2015). Some FBs are already regulating the acceptance of unhealthy foods donated, establishing guidelines and rules for donation and even refusing foods with high contents of sugar, fat and salt. There is also a proposal to review the tax exemption given to retailers who donate food of low quality (Brasil, 2019). FB also contribute to strengthening other policies and programs, such as the PAA, fostering local economy, and supporting family farming and consumption of local foods (RedeSAN, FAURGS, UFRGS \& MDS, 2011; Garcia, 2013; Rocha, 2014).

The fulfillment of the HRAF has two dimensions - preventing hunger and providing access to adequate food. Food provision is one of the HRAF dimensions, also present in Brazil's Federal Constitution and, therefore, the State has the obligation to fulfill it by means of public policies (Riches, 2018). Often, those who donate, whether in the retail chain or household, do it as a way to avoid their own waste and do not pay attention to the nutritional quality of foods. It is necessary to define criteria that are in accordance with the guidelines of healthy eating for the receipt of donations.

Finally, one major challenge faced by the implementation of EPSAN has been the low priority given to FNS by the federal government since 2014 and, consequently, the reduction in budgets directed to FNS programs - a clear breach of the State's obligations under the ICESCR, which requires the progressive realization of the HRAF for all and result in violations of the Right and worsening the conditions of life of the most vulnerable groups. Official reports indicate that, while in $2014 \mathrm{R} \$ 64$ million were allocated to EPSAN budgetary action, there were no new funds allocated in 2015 and 2016. $\mathrm{R} \$ 8.7$ million, $\mathrm{R} \$ 3.8$ million, and $\mathrm{R} \$ 0.6$ million were allocated in 2017, 2018, and 2019 respectively. In response to the COVID-19 emergency crisis, in 2020 this budget was increased to $\mathrm{R} \$ 4.6$ million, a fraction of what it had been in 2014 (Brasil, 2019).

Other FNS programs, associated with EPSAN, also suffered significant budget cuts. The Food Acquisition Program (PAA) had a 55\% reduction in the Federal Government budget since 2015, reaching only R $\$ 274$ million in 2019, and only R $\$ 100$ million in 2020 (Brasil, $2019 \mathrm{a}, \mathrm{b})$. Because it is a structuring program to shorten the commercialization and distribution circuits of family farming produces, which is closely related to the operations of Food Banks and Popular Restaurants, the dismantling of the Program directly affects the supply of food to vulnerable people.

The lack of a budget for the construction/structuring of new EPSANs over the past few years, represents a 
limitation of the capacity to offer the service provided to the population, considering that a Popular Restaurant offers, on average, 1,287 meals per day and a Food Bank benefits about 94 thousand people per month with the donation of food (Brasil, 2014). Continued budget reductions shed light on the weakened agenda of food security in Brazil and points to the need for a restructuring and prioritization of actions related to social inclusion, production and fight against poverty and extreme poverty.

\section{Final considerations}

From the perspective of the State's obligation to accomplish the Human Right to Adequate Food (HRAF), Public Infrastructure for FNS can have an important contribution on the provision dimension. It is fundamental that, along with these actions, the State develops strategies to fulfill other HRAF dimensions: respect, protection and promotion. The fulfillment of the HRAF depends on intersectoral, articulated and complementary programs for the achievement of its objectives, and includes programs with impacts on all stages of the food system: production, distribution, and consumption. Adequate funding, institutionalization, and operational processes must be secured for implementation and qualification of all these actions.

The Brazilian experience shows that effective public initiatives are possible. To promote this reality, it is necessary to strengthen the monitoring of public policies and discuss the setbacks and slowdowns that have been identified. Adequate healthy eating is an expression of citizenship and autonomy. Unfortunately, the past decade indicates a decline in the commitment of the country's federal government to a food and nutrition security agenda, reflected in the decreased budgets allocated to EPSAN and other important programs such as the PAA.

This manuscript was prepared during the Covid19 pandemic in Brazil. The sanitary and socioeconomic crisis generated as consequence of the pandemic highlights the importance of the FNS infrastructure and the need for a well-structured social protection network, able to address the humanitarian consequences in such moments of crisis.

Supplementary Information The online version contains supplementary material available at https://doi.org/10.1007/s12571-022-01272-1.

Authors' contributions All authors have contributed extensively to the work presented in this manuscript and have approved the final version.

Funding Coordination for the Improvement of Higher Education Personnel (CAPES Brazil) and Foundation for Research and Technological
Innovation of the State of Sergipe in Brazil (Fapitec Sergipe Brazil), COD. 001.

Availability of data and material (data transparency) Yes, all material is available.

Code availability (software application or custom code) Not applicable.

\section{Declarations}

Conflict of interest The authors confirm that there are no known conflicts of interest associated with this publication.

\section{References}

Abrandh. (2013). O Direito Humano à Alimentação Adequada e o Sistema Nacional de Segurança Alimentar e Nutricional. (Leão M, ed.). ABRANDH.

Belik, W., Cunha, A. R. A., \& Costa, L. A. (2012). Crise Dos Alimentos E Estratégias Para a Redução Do Desperdício No Contexto De Uma Política De Segurança Alimentar E Nutricional No Brasil. Revista Planejamento e Política Públicas., $38,107-132$.

Brasil. (2004). Manual Do Programa Restaurante Popular.

Brasil. (2005). Politica Nacional de Assistência Social (PNAS).

Brasil. (2006). Lei Orgânica de Segurança Alimentar e Nutricional. Casa Civil; 28.

Brasil. (2010). Decreto $N^{o} 7341$, de 22 de Outubro de 2010. Casa Civil.

Brasil. (2010). Emenda Constitucional $N^{\circ} 64$, de 4 de fevereiro de 2010. Altera o Art. $6^{\circ}$ Da Constituição Federal, Para Introduzir a Alimentação Como Direito Social.

Brasil. (2010). Fome Zero: Uma História Brasileira.

Brasil. (2013). Edital MDS/SESAN No 01/2013: Seleção Pública de Propostas Para Apoio à Modernização de Centrais de Recebimento de Produtos Da Agricultura Familiar, 1-33.

Brasil. (2014). Escala Brasileira de Insegurança Alimentar - EBIA: Análise Psicométrica de Uma Dimensão Da Segurança Alimentar e Nutricional. (Sardinha LMV, ed.). Ministério do Desenvolvimento Social e Combate à Fome.

Brasil. (2015). MAPASAN 2014: Mapeamento de Segurança Alimentar e Nutricional.

Brasil. (2015). Rede Brasileira de Bancos de Alimentos.; 2015.

Brasil. (2016). Portaria $N^{o} 17$, de 14 de Abril de 2016. Institui a Rede de Banco de Alimentos. Portaria n ${ }^{\circ} 17$, de 14 de abril de 2016.

Brasil. (2017). Instrução Normativa $N^{o}$ 1, de 15 de Maio de 2017. Dispõe Sobre a Adesão Dos Bancos de Alimentos à Rede Brasileira de Banco de Alimentos, 2.

Brasil. (2019). Carta de Serviços ao Usuário. Ministério da Cidadania. Published 2019. Accessed December 3, 2019. http://mds.gov.br/ acesso-a-informacao/mds-pra-voce/carta-de-servicos/gestor

Brasil. (2019). Convênio ICMS 136/19, de 12 de Agosto de 2019. Ministério da Economia. Conselho Nacional de Política Fazendária - CONFAZ.

Brasil. (2019a). Orçamento Anual de 2019 Lei Orçamentária Anual. Ministério da Economia. Published 2019. Accessed December 18, 2019. http://www.planejamento.gov.br/assuntos/orcamento-1/ orcamentos-anuais/orcamento-anual-de-2019

Brasil. (2019b). Programa de Aquisição de Alimentos - PAA. In: Ministério da Cidadania. Secretaria Nacional de Inclusão Social e Produtiva Rural. Departamento de Compras Públicas para a Inclusão Social e Produtiva Rural 36. 
Burlandy L. (2009). Programas de Segurança Alimentar e Nutricional na cidade de Toronto: Brasil e Canadá compartilhando experiências. Jornal do IBASE. Published online 5.

Calazans, D. L. M., Pequeno, N. P. F., Pereira, L. C. A., Freitas, J. F. (2018). Equipamentos públicos para promoção da alimentação adequada e saudável: um estudo nos restaurantes populares do Rio Grande do Norte. Revista da Associação Brasileira de Nutrição, 9(2):32-42.

Carrijo, A. D. P., Botelho, R. B. A., Akutsu, R. D. C. C. D. A., Zandonadi, R. P. (2018). Is what low-income Brazilians are eating in popular restaurants contributing to promote their health? Nutrients, 10(4). https://doi.org/10.3390/nu10040414

CONSEA. (2010). A Segurança Alimentar e Nutricional e o Direito Humano à Alimentação Adequada No Brasil: Indicadores e Monitoramento Da Constituição de 1988 Aos Dias Atuais.

Conti, I. L. (2009). Segurança Alimentar e Nutricional: Noções Básicas.

da Silvam, A. C. F., Recine, E., Johns, P., Gomes, F. D. S., Ferraz, M. D. A., Faerstein, E. (2018). History and challenges of Brazilian social movements for the achievement of the right to adequate food. Global Public Health, 14(6-7):875-883. https://doi.org/10. 1080/17441692.2018.1439516

de Araújo, F. R., de Araújo, M. A. D., Maia, P. B., de Medeiros, G. C. B. S., \& de Souza, F. J. V. (2016). Programa Restaurante Popular: Uma alternativa para promover o direito humano à alimentação adequada? Emancipação., 15(1), 143-154.

De Paiva, J. B., Magalhães, L. M., Dos Santos, S. M. C., Da Silva Santos, L. A., \& Trad, L. A. B. (2019). A convergence of "adequate" and "healthy": An analysis of the notion of adequate and healthy diet in public policies in Brazil. Cadernos De Saude Publica., 35(8), 1-12. https://doi.org/10.1590/0102-311X00250318

FAO. (2021). The State of Food Security and Nutrition in the World 2021. FAO, IFAD, UNICEF, WFP and WHO. https://doi.org/10. 4060/cb4474en

Fonseca, C., Scalco, M. L., \& Castro, H. C. (2018). Etnografia de uma política pública: Controle social pela mobilização popular Etnografia de uma política pública: Controle social pela mobilização popular. Horiz Antropol., 50(24), 271-303.

Garajau, N. I., \& Afonso, M. L. M. (2016). Articulação intersetorial como estratégia de gestão na Política de Segurança Alimentar e Nutricional no Brasil: Análise do Programa Cozinha Comunitária. Segurança Alimentar e Nutricional., 23(31), 1065-1079. https:// doi.org/10.20396/san.v23i0.8635603

Garcia, G. S. (2013). A Agricultura Familiar e Os Equipamentos Públicos de Segurança Alimentar e Nutricional No Distrito Federal.

Gobato, R. C., Panigassi, G., \& Villalba, J. P. (2010). Identificação do perfil de usuários de um Restaurante Popular do Município de Campinas. Segurança Alimentar e Nutricional., 17(2), 14-25.

Gonçalves, M. P., Silvana, T. D. C., \& Sarti, F. M. (2011). Políticas públicas de segurança alimentar no Brasil: Uma análise do Programa de Restaurantes Populares. Rev Gestão \& Pol Públicas., 1(1), 92-111.

Godoy, C. K., Sávio, K. E. O., Akutsu, R. C., Gubert, M. B., \& Botelho, R. A. B. (2014). Perfil e situação de insegurança alimentar dos usuários dos Restaurantes Populares no Brasil. Cad Saúde Pública., 30(6), 1239-1249. https://doi.org/10.1590/0102-311X00084013

Haug, R. (2018). Food Security Indicators: How to Measure and Communicate Results.

IFPRI. (2018). Global Food Policy Report IFPRI.

Instituto Brasileiro de Geografia e Estatistica. (2019). Pesquisa de Orçamentos Familiares 2017 - 2018: Primeiros Resultados. 1st ed. IBGE.

Leal, D. (2015). Crescimento da alimentação fora do domicílio. Segurança Alimentar e Nutricional., 17(1), 123. https://doi.org/10. 20396/san.v17i1.8634806
Machado, M. L., Gabriel, C. G., Soar, C., et al. (2018). Adequação normativa dos planos estaduais de segurança alimentar e nutricional no Brasil. Cadernos de Saúde Pública, 34(1). https://doi.org/10. 1590/0102-311x00206716

Martinelli, S. S., Bianchini, V. U., Fabri, R. K., \& Cavalli, S. B. (2018). Presença de alimentos da sociobiodiversidade em cardápios dos restaurantes populares brasileiros. Cadernos De Agroecologia., 13, 7.

Oliveira, J. T. C. D. (2018). Avaliação dos Restaurantes Populares no âmbito da Segurança Alimentar e Nutricional. Published online July 30, 2018.

ONU. (1999). Comentário Geral Número 12- Direito Humano à Alimentação (Art.11).

ONU. (1948). Universal Declaration of Human Rights.

ONU. (1975). Report of the World Food Conference (E/CONF.65/20).

Padrão, S. M., Aguiar, O. B. D. (2018). Restaurante popular: a política social em questão. Physis: Revista de Saúde Coletiva, 28(3):280319. https://doi.org/10.1590/S0103-73312018280319

Paula, N. F. D., Assis, L. D., Ribeiro, C. D. S. G., Bezerra, I. (2017). Manual of Good Practices for Food Banks: the perspective of a new construction. DEMETRA: Alimentação, Nutrição \& Saúde. 2017;12(2). https://doi.org/10.12957/demetra.2017.22877

Philip, D., Hod-Ovadia, S., \& Troen, A. M. (2017). A Technical and Policy Case Study of Large-Scale Rescue and Redistribution of Perishable Foods by the "leket Israel" Food Bank. Food and Nutrition Bulletin., 38(2), 226-239. https://doi.org/10.1177/0379572117692440

Pipkin, W. (2016). Why this Food Bank is turning away junk food? Civil Eats. Available in: https://civileats.com/2016/08/15/why-this-foodbank-is-turning-away-junk-food/

Rangel, T. (2016). O Programa Banco de Alimentos como instrumento de concepção do Direito Humano à Alimentação Adequada. Lex Humana., 8(2), 120-136.

RedeSAN, FAURGS, UFRGS, MDS. (2011). Equipamentos Públicos de Segurança Alimentar e Nutricional. Vol 1. 1st ed. Editora EVANGRAF.

Rede PENSSAN. (2021). Inquérito Nacional Sobre Insegurança Alimentar No Contexto Da Pandemia Da Covid-19 No Brasil.

Riches, G., Silvasti, T. (2014). Hunger in the rich world: food aid and right to food perspectives. In: First World Hunger Revisited: Food Charity or the Right to Food, 249.

Riches, G. E. A. (2002). Food Banks and Food Security: Welfare Reform, Human Rights and Social Policy. Lessons from Canada? Social Policy \& Administration, 36(6):648-663. https://doi.org/ 10.1111/1467-9515.00309

Riches, G. (2018). Food Bank Nations: Poverty, Corporate Charity and the Right to Food:; 2018.

Rocha, C. (2014). A Right to Food Approach: Public Food Banks in Brazil. In: Riches G, Silvasti T, eds. First World Hunger Revisited: Food Charity or the Right to Food. 2a. PalgraveMacmillan 248.

Silva, T. X. D. (2012). Avaliação Do Equipamento Público de Segurança Alimentar e Nutricional - Restaurante Popular de Santa Maria/RS

Seligman, H. K., Lyles, C., Marshall, M. B., et al. (2015). A pilot Food Bank intervention featuring diabetes-appropriate food improved glycemic control among clients in three states. Health Affairs., 34(11), 1956-1963. https://doi.org/10.1377/hlthaff.2015.0641

Soares, S. (2018). Analysis of the right to adequate food: A social and political human right. Revista De Direito Sanitario., 19(2), 36-54. https://doi.org/10.11606/issn.2316-9044.v19i2p36-54

Sobrinho, F. M., Silva, Y. C., Abreu, M. N. S., Pereira, S. C. L., \& Dias-Júnior, C. S. (2014). Fatores determinantes da insegurança alimentar e nutricional: Estudo realizado em Restaurantes Populares de Belo Horizonte, Minas Gerais Brasil. Ciência \& Saúde Coletiva, 19(5), 1601-1611. https://doi.org/10.1590/1413-81232 014195.18022013

Tenuta, N., Romero, E., \& Teixeira, A. (2017). A eficácia dos Bancos de Alimentos de Minas Gerais no combate às perdas e desperdícios de alimentos Effectiveness of Food Banks in combating food loss and 
waste in Minas Gerais. Campinas., 24(1), 53-61. https://doi.org/10. 20396/san.v24i1.8649720

UN Committee on Economic S and CR (CESCR). (1999). CESCR General Comment No. 12: The Right to Adequate Food (Art. 11).

United Nations. (1999). CESCR General comment No. 12: The right to adequate food (Art.11). Office Of The Hight Commissioner For Human Rights, 1-5.

Vasconcelos, F. D. A. G. D., Machado, M. L., Medeiros, M. A. T. D., Neves, J. A., Recine, E., Pasquim, E. M. (2019). Public policies of food and nutrition in Brazil: From Lula to Temer. Revista de Nutricao, 32. https://doi.org/10.1590/1678-9865201932e180161

Zanini, E., \& Schneider, M. B. (2015). Restaurantes Populares Em Toledo: Um Programa De Desenvolvimento. Economia e Desenvolvimento., 27(2), 243-256. https://doi.org/10.5902/1414650920984
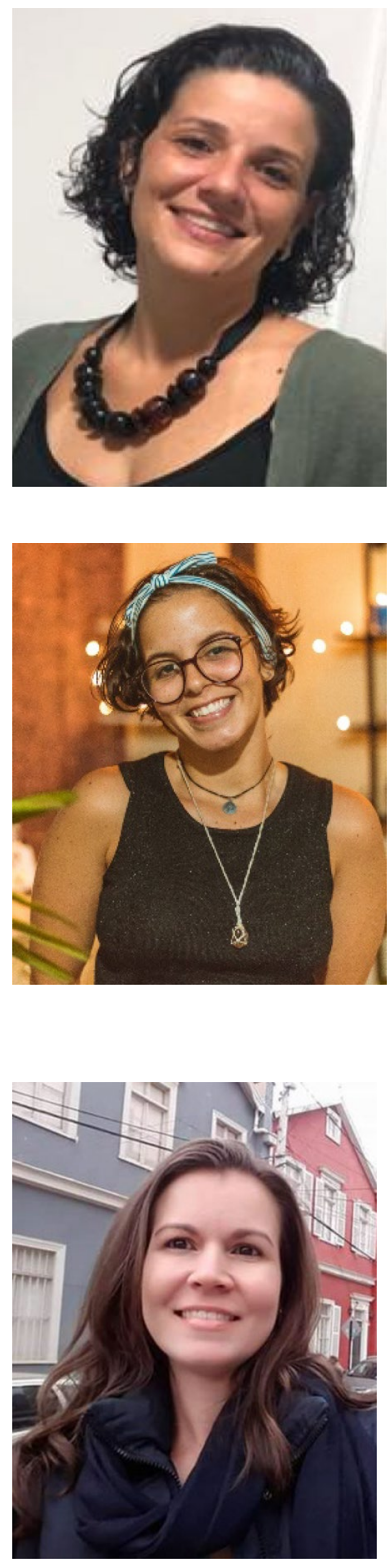

University of Goiás. Professional experience in nutrition and communities. Currently she works at the Ministry of Citizenship management of public policies on food and nutrition security.

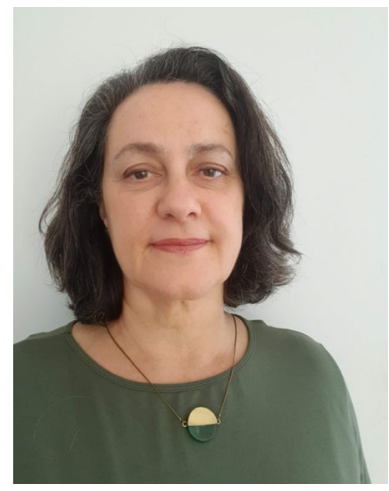

Dr.Elisabetta Recine Nutritionist with a PhD in Public Health. Professor at the University of Brasília, Brazil, Department of Nutrition, Faculty of Health Sciences, she has academic and governmental experience in food and nutrition policies, food and nutrition security and the right to food. Currently she is also the Coordinator of the Observatory for Food and Nutrition Security Policies of the University of Brasília. Member of the StC of the Brazilian Alliance for Healthy and Adequate Food a network of civil society organizations and academics for FNS policies advocacy. Member of the Advisory Committee - Brazilian Network for Research in Sovereignty and Food and Nutrition Security. Member of the Project Team - 12th HLPE Report Nutrition and Food Systems. Member of the HLPE StC 2017-2019.

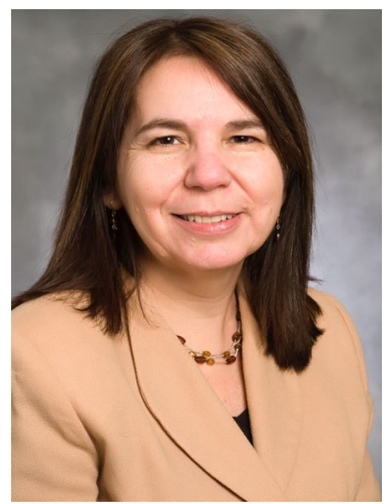

Dr.Cecilia Rocha $\mathrm{PhD}$, is the Director of the Centre for Studies in Food Security and a Professor in the School of Nutrition, Ryerson University, Canada. A member of the International Panel of Experts on Sustainable Food Systems (IPESFood), she was the lead author of the report Unravelling the FoodHealth Nexus: Addressing practices, political economy, and power relations to build healthier food systems (2017). Cecilia has participated in the development of the Toronto Food Strategy (2008-2010), and was a member of the Toronto Food Policy Council (2005-2011). She has done research on the role of food in the lives of recent immigrant women, and on food insecurity among Latin American recent immigrants in Toronto. She was the director of the project Building Capacity in Food Security in Brazil and Angola (2004-2010), and co-director of the project Scaling up small-scale food processing for therapeutic and complementary food for children in Vietnam (2015-2018). Considered an expert on the innovative approach to food and nutrition security in the city of Belo Horizonte, Cecilia is the author of a number of scholarly papers and reports on food policy and programs in Brazil. 